\title{
NON-ENGLISH MAJORS' ATTITUDES TOWARDS THE USE OF ENGLISH CAPTIONED VIDEOS IN ENGLISH CLASS
}

\author{
Nguyen Dinh Nhu $\mathrm{Ha}^{1}$, Tran Quoc Thao ${ }^{2 *}$ \\ ${ }^{1}$ Institute of International Education, Ho Chi Minh City University of Technology (HUTECH) \\ ${ }^{2}$ Faculty of English Language, Ho Chi Minh City University of Technology (HUTECH)
}

\section{ABSTRACT}

This paper aims at presenting students' attitudes towards the use of English captioned movies in English classes at Ho Chi Minh City Industry and Trade College. One hundred and fifty college freshmen who were studying Information Technology, Mechanics, Accounting, Electronics and Business Administration participated in answering the questionnaire, and twenty-five students of them were invited to take part in the semi-structured interviews. The quantitative data gained from the questionnaires were analyzed employing SPSS in terms of descriptive statistics and ANOVA test, while the qualitative data were analyzed using the content analysis approach. The results showed that participants expressed positive attitudes towards the use of English captioned movies in English classes, and they had affective attitudes towards the use of English captioned movies higher than their cognitive and behavioral attitudes. The results further indicated that participants had similar attitudes towards the use of English captioned movies regardless of their majors.

Keywords: attitudes; English captioned movies; listening skills; non-English majors; English class

\section{THÁI Độ CỦA SINH VIÊN KHÔNG CHUYÊN ĐỐI VỚI VIẸC SỬ DỤNG PHIM CÓ PHỤ ĐỂ TIẾNG ANH TRONG LỚP HỌC TIỂNG ANH}

\author{
Nguyễn Đình Như Hà ${ }^{1}$, Trần Quốc Thao ${ }^{2 *}$ \\ ${ }^{I}$ Viện Đào tạo Quốc tế, Trừ̀ng Đại học Công nghệ Thành phố Hồ Chí Minh (HUTECH) \\ ${ }^{2}$ Khoa tiếng Anh, Truòng Đại học Công nghệ Thành phố Hồ Chi Minh (HUTECH)
}

\section{TÓM TẮT}

Nghiên cứu này nhằm tìm hiểu thái độ của sinh viên đối với việc sử dụng phim có phụ đề tiếng Anh trong lớp học tiếng Anh tại Trường Cao đẳng Công Thương Thành phố Hồ Chí Minh. Có 150 sinh viên năm nhất thuộc các chuyên ngành Công nghệ thông tin, Cơ khí, Kế toán, Điện tử và Quản trị kinh doanh tham gia nghiên cứu bằng việc trả lời bảng hỏi và 25 sinh viên tham gia phỏng vấn. Dữ liệu thu thập được từ bảng hỏi và phỏng vấn được xử lý bằng phần mềm thống kê SPSS và phân tích nội dung khảo sát. Kết quả nghiên cứu cho thấy rằng các sinh viên có thái độ tích cực đối với việc sử dụng phim có phụ đề tiếng Anh và mặt cảm xúc của họ cao hơn so với mặt hành vi và nhận thức về việc sử dụng phim có phụ đề tiếng Anh. Bên cạnh đó, kết quả nghiên cứu đã chỉ ra rằng dù các sinh viên có chuyên ngành học khác nhau nhưng thái độ đối với việc sử dụng phim có phụ đề tiếng Anh trong lớp học là như nhau.

Từ khóa: thái độ; phim có phu đề tiếng Anh; kỹ năng nghe; sinh viên không chuyên; lóp học tiếng Anh

Ngày nhận bài: 13/7/2020; Ngày hoàn thiện: 11/8/2020; Ngày đăng: 12/8/2020

* Corresponding author. Email: tq.thao@hutech.edu.vn

DOI: https://doi.org/10.34238/tnu-jst.3404

http://jst.tnu.edu.vn; Email: jst@tnu.edu.vn 


\section{Introduction}

It is evident that listening is considered one of the most important skills for foreign language learners [1], [2]. It results from the fact that listening plays a major role in everyday communication. According to Morley [3], "Listening is the most common communicative activity in daily life: we can expect to listen twice as much as we speak, four times more than we read, and five times more than we write" (p.81). Moreover, it will be against the naturalistic approach of acquiring a language and cause "cognitive overload" if learners are forced to produce the forms that they have not acquired yet [4]. In other words, learners should receive input before switching to any other stage of language learning. Listening, then, provides them with input. However, according to Walker [5], listening is seen as one of the most difficult skills. That is why ESL/EFL teachers should seek for some way to facilitate their learners' listening process. Traditionally, listening activities were believed to consist of only some typical tasks such as listening to a recording and doing some following tasks, listening to teachers and repeating, listening to songs, or dictation. Nowadays, with the support of technology, teachers are enabled and encouraged to apply innovative multimedia tools to the teaching. Baltova [6] points out that movies are effective and powerful tools to attract viewers' attention and encourage them to improve listening skills for understanding the contents. Videos, as a result, become an extremely useful source of listening materials since it provides learners with both audio and visual input. Further than that, not only is the image added to the sound, but the captions can also facilitate listening process. In terms of attitudes, they are supposed to directly influence behavior [7] - [10]. Hewstone and Stroebe [11] demonstrated that the more positive attitude a person has about his level of intelligence, the more he thinks that he could solve the problems. In addition, Conner and Armitage [12] have expressed that the components of attitudes are considered a person's obvious behavioral beliefs which represent outcomes of the behavior. In general, the aims of this study are (1) to find out the non-English majors' attitudes towards the use of English captioned movies in English class and (2) to examine the differences in nonEnglish majors' attitudes towards the use of English captioned movies in terms of different majors. In order to achieve the aforementioned objectives, the following research questions are addressed: (1) What are non-English majors' attitudes towards to the use of English captioned movies in English class? (2) Do students from different majors differ in attitudes towards to the use of English captioned movies? If yes, how?

\section{Methodology}

\subsection{Research setting and participants}

This research was carried out at Ho Chi Minh City Industry and Trade College which consists of 12 departments, with the total of over 4000 students. The participants of the present study consisted of 150 freshmen who were purposively sampled. The number of male and female was $54.7 \%$ and $45.3 \%$ respectively. Students with 11 and 7 years of learning English were $26 \%$ and $74 \%$ respectively. The students were from Faculty of Information Technology (40\%) and the others were mechanics students (18\%), accounting students (20\%), electronics students (12\%), and business administration students (10\%). Time for listening activity was categorized into 4 main groups. The first group with less than one hour was $56.7 \%$. The group of 1-3 hours a day was $40.7 \%$. The third group with 3-5 hours was $2.0 \%$. The last group spending more than 5 hours a day was $0.7 \%$. 


\subsection{Research instruments}

The instruments employed in the study include a closed-ended questionnaire and semi-structured interview. The questionnaire was designed with a 5-point Likert scale ranging from 1 to 5 ( $1=$ strongly disagree, 2 = disagree, $3=$ neutral, $4=$ agree, $5=$ strongly agree). The questionnaire was divided into two parts with the total number of 25 items. The Cronbach's Alpha of questionnaire was .943. The semi-structured interview was used to gain an insight into the attitudes towards the use of captioned movies. Twenty-five participants were invited for interviews. The questionnaire and interview were also translated into Vietnamese.

\subsection{Procedures for data collection and analysis}

For the data analysis, the quantitative data were processed using SPSS 22.0, while the content analysis was employed dealing with qualitative data. The meanings of the mean scores for the students' attitudes towards the use of English captioned videos were interpreted as follows: Strongly disagree (1 $1.80)$; disagree (1.81 - 2.60); neutral (2.61 $3.40)$; agree $(3.41-4.20)$ and strongly agree (4.21 - 5.00). The interviewees were labeled from S1 to S25.

\section{Findings and discussion}

\subsection{Findings}

3.1.1. Non-English majors' attitudes towards the use of English captioned movies in English class

Table 1. Students' attitudes towards the use of English captioned movies

\begin{tabular}{cccc}
\hline \multirow{2}{*}{ No. } & \multirow{2}{*}{ Attitudes } & \multicolumn{2}{c}{ N=150 } \\
\cline { 3 - 4 } & & $\mathbf{M}$ & SD \\
\hline 1 & Cognitive attitudes & 3.60 & .82 \\
2 & Affective attitudes & 3.81 & .79 \\
3 & Behavioral attitudes & 3.62 & .86 \\
& Total & $\mathbf{3 . 6 7}$ & $\mathbf{. 8 2}$ \\
\hline
\end{tabular}

Table 1 showed that the total mean scores of attitudes towards the use of English captioned movies was rather high $(\mathrm{M}=3.67 ; \mathrm{SD}=.82)$. It means that participants' attitudes were relatively positive. The single most striking observation to emerge from the data comparison was that the affective attitudes were the highest component $(\mathrm{M}=3.81 ; \mathrm{SD}=.79)$. The following was behavioral one $(\mathrm{M}=3.62$; $\mathrm{SD}=$ .86). The cognitive component ranked the third $(\mathrm{M}=3.60 ; \mathrm{SD}=0.82)$.

\section{Cognitive attitudes}

As seen in Table 2, participants agreed that English captioned movies helped them receive the information from conversation (item 3: $\mathrm{M}=3.73 ; \mathrm{SD}=.87$ ). Besides, participants could improve pronunciation through watching English captioned movies (item 5: $\mathrm{M}=3.67 ; \mathrm{SD}=.79$ ). Besides participants agreed that their ability of recognizing the important information and understanding the story of movies was improving critically (item $4: \mathrm{M}=3.65$; $\mathrm{SD}=$ .86 and item 7: $\mathrm{M}=3.65 ; \mathrm{SD}=.76$ ). Regarding listening skills, participants also agreed that their listening skills improved when reading captions on the screen (item 2: $\mathrm{M}=3.59 ; \mathrm{SD}=.79$ ). Furthermore, these movies helped students to enhance listening skills (item $1: \mathrm{M}=3.55 ; \mathrm{SD}=.79$ ). Concerning to the learning outcome, participants admitted that their learning outcomes improved (item 8: $\mathrm{M}=3.49 ; \mathrm{SD}=.78$ ). Participants also agreed that their speaking competence could improve (item 6: $\mathrm{M}=3.46 ; \mathrm{SD}=.88$ ). These findings can be interpreted that English captioned movies helped participants improve their listening and speaking skills as well as learning outcomes. Participants had more chances to practise pronunciation and ability of defining important information from English movies. Moreover, participants become more confident when they could understand the whole story of the movies. 
Table 2. Students' cognitive attitudes towards the use of English captioned movies

\begin{tabular}{llcc}
\hline \multirow{2}{*}{ No. } & \multicolumn{1}{c}{ Cognitive Attitudes } & N=150 \\
\cline { 2 - 4 } & & M & SD \\
\hline 1 & Captioned movies help me to enhance my listening skills. & 3.55 & .79 \\
2 & I can improve my listening skills when reading captions on the screen. & 3.59 & .79 \\
3 & Captioned movies help me to receive the information from conversations. & 3.73 & .87 \\
4 & I can understand the whole story of movies by watching captions. & 3.65 & .86 \\
5 & I can improve my pronunciation by listening and watching captions. & 3.67 & .79 \\
6 & I can improve my speaking competence by watching captions. & 3.46 & .88 \\
7 & I improve my ability to recognize the important information from watching & 3.65 & .76 \\
8 & caption movies. & 3.49 & .78 \\
& My learning outcomes can improve after watching captioned movies. & $\mathbf{3 . 6 7}$ & $\mathbf{. 8 2}$ \\
\hline
\end{tabular}

The participants taking part in the interview admitted that watching English captioned movies was useful and important for their listening skills. They also reported some reasons for that:

...Thanks to captioned movies, students speak more fluently and understand many new structures. (S2)

...English captioned movies help students pronounce well. (S5)

...Students can understand stories of movies better. (S14)

Moreover, from the interview data, it was noticeable that participants could improve their listening skills, some of which were listed as follows:

...Putting stresses and using intonation is becoming more effective and correct. (S25)

...English captioned movies help students to distinguish accents. (S20)

\section{Affective attitudes}

As can be noted in Table 3, participants felt more confident to evaluate their listening competence (item 12: $\mathrm{M}=3.98 ; \mathrm{SD}=.74$ ). Thus, participants found it enjoyable to cooperate with classmates to do listening tasks (item 11: $\mathrm{M}=3.91 ; \mathrm{SD}=.81$ ). Participants also agreed that they felt interested in engaging more in listening activities (item 10; $\mathrm{M}=3.83 ; \mathrm{SD}=.83$ ). They were able to correct listening exercises in front of class (item 14: $\mathrm{M}=3.76$; $\mathrm{SD}=.82$ ). In addition, they felt more confident to finish listening tasks (item 9: $\mathrm{M}=3.70 ; \mathrm{SD}=.70$ ). Participants thought that they could define main ideas from the recordings by themselves (item 13; $\mathrm{M}=3.69 ; \mathrm{SD}=.82$ ). To put it briefly, participants had positive affective attitudes in listening period. They became more confident, enjoyable, engaged and interested in listening activities.

Table 3. Students' affective attitudes towards the use of English captioned movies

\begin{tabular}{llcc}
\hline \multirow{2}{*}{ No. } & Affective Attitudes & \multicolumn{2}{c}{ N=150 } \\
\cline { 3 - 4 } & & M & SD \\
\hline 9 & I feel more confident to finish listening tasks. & 3.70 & .70 \\
10 & I find it interesting to engage more in listening activities. & 3.83 & .83 \\
11 & I find it enjoyable to cooperate with my classmates to do listening tasks. & 3.91 & .81 \\
12 & I find it confident to evaluate my listening competence. & 3.98 & .74 \\
13 & I feel confident to define main ideas from the recordings. & 3.69 & .82 \\
14 & I find it confident to correct listening activities in front of class. & 3.76 & .82 \\
& Total & $\mathbf{3 . 8 1}$ & $\mathbf{. 7 9}$ \\
\hline
\end{tabular}


From the data collected in the interview, it was evident that participants had positive affective attitudes towards the use of English captioned movies.

...I feel confident to volunteer to correct listening exercises from the teachers. (S1)

...I volunteer to answer listening activities after watching captioned movies. (S12)

\section{Behavioral attitudes}

Table 4 shows that participants often looked for more interesting captioned movies for extra practice (item $15: \mathrm{M}=3.77$; $\mathrm{SD}=.84$ ). Participants agreed that when watching English captioned movies, they often wrote down interesting words and phrases (item 16: $\mathrm{M}=3.72 ; \mathrm{SD}=.86)$. Furthermore, participants spent more time re-watching movies (item: $17, \mathrm{M}=6.63$; $\mathrm{SD}=.84$ ). As results of practicing at home and looking for more movies, participants reported that their listening skills had improved (item 1.19: $\mathrm{M}=$ $3.61 ; \mathrm{SD}=.87$ ). With regard to favorite kinds of movies, participants also admitted that when watching favorite movies, they paid much attention (item: $18, \mathrm{M}=3.39$; $\mathrm{SD}=$ .87). In summary, participants expressed positive behavioral attitudes towards the use of English captioned movies.

In the interview, students showed their agreement as follows:

...I can improve my listening skills by rewatching captioned movies for at least three times at home. (S3)

...I practise shadowing short sentences of some characters in most of captioned movies. (S22)

\subsubsection{Differences in non-English majors} attitudes towards the use of English captioned movies in terms of majors

The results from one-way ANOVA in Table 5 indicated that there was no statistically significant difference in non-English majors' attitudes towards the use of English captioned movies $(\mathrm{F}=.126$; $\mathrm{Sig}=.973)$ in terms of majors. This means that although students were from different majors, they had similar attitudes towards the use of English captioned movies.

Table 4. Students' behavioral attitudes towards the use of English captioned movies

\begin{tabular}{|c|c|c|c|}
\hline \multirow{2}{*}{ No. } & \multirow{2}{*}{ Behavioral Attitudes } & \multicolumn{2}{|c|}{$\mathbf{N}=150$} \\
\hline & & $\mathbf{M}$ & SD \\
\hline 15 & I find more interesting captioned movies to practise listening. & 3.77 & .84 \\
\hline 16 & $\begin{array}{l}\text { I always take notes of interesting words and phrases when watching } \\
\text { captioned movies. }\end{array}$ & 3.72 & .86 \\
\hline 17 & I spend more time rewatching captioned movies at home. & 3.63 & .84 \\
\hline 18 & I pay much attention to my favorite kinds of movies. & 3.39 & .87 \\
\hline 19 & $\begin{array}{l}\text { My listening skills have improved since I practised watching captioned } \\
\text { movies at home. }\end{array}$ & 3.61 & .87 \\
\hline & Total & 3.62 & .86 \\
\hline
\end{tabular}

Table 5. Difference in attitudes towards the use of English captioned movies in terms of majors

\begin{tabular}{|c|c|c|c|c|c|c|c|}
\hline \multirow{2}{*}{ Factors } & \multirow{2}{*}{ Sig. } & \multirow{2}{*}{$\mathbf{F}$} & \multicolumn{5}{|c|}{ M(SD) } \\
\hline & & & IT & $\mathbf{M}$ & $\mathbf{A}$ & $\mathbf{E}$ & BA \\
\hline $\begin{array}{l}\text { Attitudes towards the } \\
\text { use of English } \\
\text { captioned movies }\end{array}$ & .973 & .126 & $\begin{array}{l}3.64 \\
(.66)\end{array}$ & $\begin{array}{l}3.73 \\
(.50)\end{array}$ & $\begin{array}{l}3.70 \\
(.46)\end{array}$ & $\begin{array}{l}3.68 \\
(.51)\end{array}$ & $\begin{array}{l}3.64 \\
(.70)\end{array}$ \\
\hline
\end{tabular}




\subsection{Discussion}

The findings of the study revealed students' positive attitudes towards the use of English captioned movies. In terms of cognitive attitudes, the findings were corroborated with the ideas of [13], who has suggested that the cognitive process in listening consists of receiving, construction and interpreting the spoken language. The results of this study indicated that students followed the process seriously. Participants agreed that they could improve their ability of receiving the information from captioned movies, construct and improve their pronunciation, reading skills as well as speaking skills. Moreover, students were aware of the usefulness of English captioned movies to listening skills. These findings were partially supported by the previous research carried out by [14] [24] who proved that students could understand the stories of movies, listen better, increase listening comprehension, expand new lexicons and phrases by watching English captioned movies. Concerning affective attitudes, the present findings seemed to be consistent with [25] - [27]. The findings unfolded that students felt more confident to evaluate their listening experience, felt interested to engage more in listening tasks. In addition, it was concluded that students (56.7\%) actively engaged in listening activity with one hour a day. In addition, the majority of participants agreed that they were interested in captioned movies. In particular, students (53.3\%) were interested in cartoon movies. They also felt less anxious to engage in most of the listening tasks in class. This also accorded with [28], who have found out that students had good motivation and became more confident to watch English captioned movies. Regarding behavioral attitudes, this study produced results which were corroborated the findings of a great deal of the previous work in this field. In the same line with [14], [29] the findings revealed that students spent more time finding captioned movies for extra practice or re-watching inclass movies at home, often took notes of interesting information to improve their listening skills and looked for more favorite captioned movies to practice. Secondly, the findings showed that majors did not affect participants' attitudes towards the use of English captioned movies. The first reason might be that students realized the important role of English captioned movies. The second reason could be explained that students were interested in English caption movies. Finally, it might be the reason of strict obligations in class. All of the majors must follow regulations during listening periods.

\section{Conclusion and implications}

The results of this study shed light on students' attitudes towards the use of English captioned movies. One of the significant findings to emerge from this study was that students had positive attitudes towards the use of English caption movies in terms of cognitive attitudes, affective attitudes and behavioral attitudes. The findings suggest several courses of action for the administrations, the teachers in charge of teaching general English and students in general English classes. For the administrators, they should either allow more time for the general English course or reduce the number of students in a class. For the English teachers, they have to make sure that students fully understand the effectiveness of English captioned movies. The teachers should design both in-class and out-of-class tasks with more activities for the students. To the students in general English classes, they should be aware of the importance and usefulness of captioned movies to improve listening skills and formulate positive attitudes towards listening skills. 


\section{REFERENCES}

[1]. T. Q. Tran and T. M. Duong, "Insights into Listening Comprehension Problems: A Case Study in Vietnam," PASAA, vol. 59, pp. 77100, 2020.

[2]. H. L. Nguyen and T. M. N. Le, "Facilitating Listening and Speaking skills for English majors at tertiary education through the use of Moodle," Journal of Science, vol. 1, pp. 3-17, 2020.

[3]. J. M. Morley, Listening Comprehension in Second/ Foreign Language Instruction, New York: Newbury House, 1991.

[4]. L. Vandergrift, "Facilitating second language listening comprehension: acquiring successful strategies," ELT Journal, vol. 53, no. 3, pp. 168-276, 1999.

[5]. N. Walker, "Listening: The most difficult skill to teach," Encuentro, vol. 23, pp. 167175, 2014.

[6]. I. Baltova, "Multisensory language teaching in a multidimensional curriculum: The use of authentic bimodal video in core French," The Canadian Modern Language Review, vol. 56, no. 1, pp. 32-48, 1999.

[7]. T. N. P. Tran and T. Q. Tran, "Attitudes towards the Learning of Culture in English Language Learning Among Vietnamese High School Students," Proceedings of the Third International TESOL Conference Promoting ELT: Diverse Perspectives and New Horizons at Ho Chi Minh City University of Education, pp. 233-246, 2017.

[8]. T. Q. Tran and T. M. Duong, "The Attitudes towards English Language Learning and Use of Self-Regulated Learning Strategies among College Non-English Majors," International Journal of Scientific and Research Publications, vol. 3, no. 7, pp. 1-8, 2013.

[9]. T. Q. Tran, T. M. Duong and N. T. T. Huynh, "Attitudes toward the Use of TELL Tools in English Language Learning among Vietnamese Tertiary English Majors," VNU Journal of Social Sciences and Humanities, vol. 5, no. 5, pp. 581-594, 2019.

[10]. T. Q. Tran and S. Seepho, "EFL Learners' Attitudes toward Intercultural Communicative Language Teaching and their Intercultural Communicative Competence Development," Journal of English Studies, vol. 11, pp. 1-40, 2016.

[11]. M. Hewstone and W. Stroebe, Introduction to social psychology: A European perspective. MA: Blackwell Publishing, 2004.
[12]. M. Conner and C. Armitage, "Extending the theory of planned behavior: A review and avenues for further research," Journal of applied social psychology, vol. 28, no. 15, pp. 1429-1464, 1998.

[13]. M. Rost, "L2 listening", in Handbook of research on second language learning and teaching, E. Hinkel ed. Mahwah, NJ: Erlbaum, 2005, pp. 503-527.

[14]. P. Markham et al., "The effects of native language vs. target language captions on foreign language students' DVD video comprehension," Foreign Language Annals, vol. 35, no. 5, pp. 439-445, 2001.

[15]. S. A. Bird and J. N. Williams, "The effect of bimodal input on implicit and explicit memory: An investigation into the benefits of within-language subtitling," Applied Psycholinguistics, vol. 23, no. 4, pp. 509-533, 2002.

[16]. J. T. Pujola, "CALLing for help: Researching language learning strategies using help facilities in a web-based multimedia program," ReCALL, vol. 14 , no. 2, pp. 235262, 2002.

[17]. J. Froehlich, "German videos with German subtitles: A new approach to listening comprehension development," Die Unterrichtspraxis/ Teaching German, vol. 21, no. 2, pp. 199-203, 1998.

[18]. K. Wang and H. Liu, "Language acquisition with the help of captions," Studies in Literature and Language, vol. 3, no. 3, pp. 41-45, 2011.

[19]. M. Mansory, "Subtitle's effect on the listening comprehension of the viewer \& viewers' attitude," Master's thesis, Northern Cyprus: Eastern Mediterranean University, 2015.

[20]. T. Pimsamarn, “A survey of students' opinions on watching English soundtrack movie to enrich listening skill development," Master's thesis, Thailand: Language Institute, Thammasat University Bangkok, 2011.

[21]. T. Garza, "Evaluating the use of captioned video materials in advanced foreign language learning," Foreign Language Annals, vol. 24, no. 3, pp. 239-258, 1991.

[22]. Z. Nafissi, "The effects of using English captions on Iranian EFL students' listening comprehension," Procedia - Social and Behavioral Sciences, vol. 64, pp. 105-112, 2012.

[23]. T. H. Nguyen, "Using movies to increase motivation and listening comprehension of third-year EFL students at Academy of Finance," Master's thesis, University of 
Languages and International Studies, Hanoi, 2014.

[24]. T. T. Nguyen, "A minor study on main difficulties in learning listening skills perceived by first-year students of faculty of English teacher education, ULIS, VNU," Master's thesis, University of Languages and International Studies, Hanoi, 2013.

[25].S. C. Chaiken, Attitude structure and function. New York: McGraw-Hill, 1998.

[26]. J. Safranj, "Advancing listening comprehension through movies,"
ProcediaSocial and Behavioral Sciences, vol. 191, pp. 169-173, 2005.

[27]. R. Vanderplank, "The value of teletext subtitles in language learning," ELT Journal, vol. 42, no. 4, pp. 272-281, 1988.

[28]. N. T. T. Hoang, "What do learners of technology say about self-directed English learning with technology," VNU Journal of Foreign Studies, vol. 1, pp. 118-132, 2017.

[29]. M. L. Defleur and F. R. Westie, "Attitude as a scientific concept," Social Forces, vol. 42, no. 1, pp. 17-31, 1963. 